The University of Southern Mississippi

The Aquila Digital Community

Faculty Publications

$12-1-2001$

\title{
Powwows and Identity on the Piedmont and Coastal Plains of North Carolina
}

Chris J. Goertzen

University of Southern Mississippi, Christopher.Goertzen@usm.edu

Follow this and additional works at: https://aquila.usm.edu/fac_pubs

Part of the Music Commons

\section{Recommended Citation}

Goertzen, C. J. (2001). Powwows and Identity on the Piedmont and Coastal Plains of North Carolina. Ethnomusicology, 45(1), 58-88.

Available at: https://aquila.usm.edu/fac_pubs/3739

This Article is brought to you for free and open access by The Aquila Digital Community. It has been accepted for inclusion in Faculty Publications by an authorized administrator of The Aquila Digital Community. For more information, please contact Joshua.Cromwell@usm.edu. 


\title{
Powwows and Identity on the Piedmont and Coastal Plains of North Carolina
}

\author{
CHRIS GOERTZEN / University of Southern Mississippi
}

( n March 10, 1997, an unsigned editorial entitled "A Tribe is a Tribe" appeared in the Raleigh, North Carolina News and Observer: ${ }^{1}$

. . . it's rather quizzical that North Carolina's Commission of Indian Affairs ... refuses to grant tribal status to . . . the Occaneechi Band of the Saponi Nation. The Commission's reason for refusal [is that the petitioners] can show no longstanding governmental structure that proves they were a tribe. Yet the Occaneechi . . . have lived . . . in Alamance County for as long as anyone can recall. An anthropologist hired by the Commission said they satisfied the state's criteria for tribal status.

Commission members, who set Indian policy in North Carolina, understandably worry about the current fad for anything Indian. . . . And the Occaneechi harmed themselves a few years ago when they adopted some customs and regalia [i.e., powwow culture] from western U.S. tribes. . . But that lapse can be forgiven. . . . [Economic benefits would be minimal, but] recognition by the state would offer the Occaneechi their taste of official cultural pride.

Most of the members of the North Carolina Commission of Indian Affairs are Indians representing the seven tribes and three urban intertribal organizations that do have state recognition. The Occaneechi-Saponi, a much smaller group than any with seats on the Commission, have a long history in north-central North Carolina. To achieve state recognition, they must document how they fulfill at least five of eight criteria set by the Commission, criteria that emphasize continuities of blood-persisting family names, kinship relationships with recognized tribes, group genealogiesand of location, and also take into account earlier descriptions of individuals and communities as Indian. Expressive culture appears only in the seventh of the eight criteria: "documented traditions, customs, legends, etc. that signify the tribe's Indian heritage." 2

The Commission's bylaws charge it to help groups like the Occaneechi with their applications, yet the process remains antagonistic. This per-

(C) 2001 by the Board of Trustees of the University of Illinois 
petuates centuries of factionalism between and within North Carolina Indian populations, factionalism that now perversely celebrates the value of community by arguing about who belongs to this one. Many modern Indian wars concern official recognition, and are fought in the courts, both between Indian populations (the case here), and between Indian groups and the federal government (Nagel 1996:22, 53; Clifford 1988). As of this writing, the Commission has denied state recognition to the Occaneechi three times, in 1995, 1997, and 1999. The reasoning behind this seems as informal as legalistic: Commission members supplement their own statutes with strongly-felt personal opinions of what "Indian" and "tribe" mean. For instance, in a 1998 court hearing, one Commission member testified that "You might have Indian heritage, but if you don't live as an Indian, you're not a [member of a] tribe" (D. Smith 1998:5). Whatever this means, it is not among any official criteria. Another Commission member demanded evidence of a continuous political organization, which is required for federal recognition, but is not among the state criteria. The newspaper editor quoted above, although sympathetic to the Occaneechi petition, also reaches beyond the official criteria into the realm of contemporary expressive culture in criticizing the Occaneechi's "adopting [of] customs and regalia from the West," i.e., participation in national powwow culture. But Commission members would certainly not agree with that editor that this constituted a lapse in articulating identity: nearly all North Carolina Indian communities and intertribal organizations cultivate the powwow as their main distinctively Indian public group experience.

The most active of the groups that founded the state Commission of Indian Affairs in 1971 put on the first North Carolina powwows at about the same time. Chief W. R. Richardson, visionary leader of the Haliwa-Saponi for over four decades, attended powwows during travel to New England, and arranged North Carolina's first in 1966 in order to honor the state's official recognition of the tribe the previous year. At about 3000 members, the Haliwa-Saponi are about seven times as numerous as the Occaneechi-Saponi, and the third largest Indian community in North Carolina, after some 45,000 Lumbee in the Southeastern corner of the state and over 9000 Eastern Cherokee, among a total of over 80,000 Indians in the state - the largest Indian population east of the Mississippi (North Carolina Commission of Indian Affairs 1987). The Haliwa-Saponi have long resided northeast of Raleigh in Halifax and Warren counties: hence "Haliwa," adopted as the tribal name in 1953 . The conversation about that name continued, starting in the late 1960s, refocused on which ancestral strand dominated-Saponi, Nansemond, Tuscarora, Occaneechi, Tutelo, or Gingaskin; "Saponi" was appended to "Haliwa" in 1979 (see Haliwa-Saponi Tribe 1997:39). 
In the eastern two-thirds of North Carolina, the Piedmont and Coastal Plains, Indian communities have long centered on churches and on schools. Community leaders were church deacons. Many Haliwa-Saponi attended Indian churches since the first local one was founded in the 1860s (Haliwa-Saponi Tribe 1997). Some of these churches remain largely Indian, but those of smaller groups like the Occaneechi-Saponi have seen their Indian character diluted or lost in recent decades. But churches proved easier to keep Indian than schools: churches are attended by choice and by more family members than would enroll in a given school, and churches can remain viable even if membership dips well below one hundred. An independent Haliwa-Saponi Indian school, built in 1957, was closed due to desegregation in 1968: its loss is still keenly felt (Lynch 1997). Indeed, many Indian schools were closed in 1965-69 (listed in Perdue 1985:66). Integration affected Indian schools in proportion to population. Small groups like the Occaneechi-Saponi did not have separate Indian schools at this time, despite repeated entreaties, though their children were concentrated in one school. Medium-sized groups including the Haliwa-Saponi found their precious separate schools closed, and their children, suddenly and painfully in the minority in the classroom, bussed long distances to be bullied by both whites and blacks (Lynch 1997). The much more numerous Lumbee remained in the majority at some of their schools, though integration was aggressive, controversial, and resisted both on the spot and in court (Gaillard 1971:8; Hazel 1985:28-29; Sider 1994:61). Although the long-term benefits of the Civil Rights movement have been critical in slowly creating a climate of tolerance, desegregation was initially a crude instrument, devastating to North Carolina Indian communities.

These changes added dramatically to the general disruption of rural life that followed World War II, disruption caused by growing populations, industrialization, and the reduced viability of small farms. These national trends caused painful out-migration not just from rural Indian communities but similar movement from countryside to city nationwide, inspiring "intense fermentation at the grassroots level of culture" in many ethnic groups (Jabbour 1993:9). North Carolina Indian culture was already fragile following three centuries of prejudice and mistreatment. Creating the North Carolina Commission of Indian Affairs and arranging the first local powwows were complementary (and often explicitly linked) responses to the assault on community by integration-which was itself not a force acting alone, but a large last straw. In terms of Victor Turner's model of social drama, the first stage, the "breach" in Indian identity, was centuries in the making, integration constituted the "crisis," and powwows and the various functions of the North Carolina Commission of Indian Affairs all parts of "redressive process." Turner postulates three categories of this process, "ritual" (here, powwows), "legal-judicial" (the hurdle of state recognition), 
and "political" (both). Closure in terms of his model, either "reintegration" or "recognition of irreparable schism," seems unlikely. Indians are not treated nearly as badly today as in the past, but certainly will never receive fair recompense for all that has been taken from them-hence the continued need for both channels of "redressive process" (Turner 1990:10; see also Lerch 1993). I will focus on the nature and brief history of the powwow in North Carolina for most of this essay, but will periodically circle back to how the question of state recognition has interacted with the cultivation of the powwow, and will close with a consideration of the current entanglement of those arms of "redressive process."

Just as the powwow answered community needs that had burgeoned in recent decades, it slid smoothly into an existing ceremonial niche in this region. There already were regular gatherings of various Indian populations-composed of both residents and emigrants visiting home-particularly Protestant revivals. Occaneechi-Saponi Chairperson John Jeffries, an elder who has had an enormous impact on recent community history, described the Baptist "Associations" of his youth to me:

The 'sociation was very, very similar to your fall festivals. They happened in the hot time of the year. . . harvest time. That was when they had all of the foods and things that they'd grown through the year. . . I remember a lot of, for instance, dried peach pieces. They had all kinds of vegetables there. Watermelons were in season at that time, and all kinds of poultry, wild meats, and just whatever the families could get together: that's what they had to eat.

And they had what they call a brush arbor there. Usually it was around the church somewhere; it was centered around the church. ... on Sundays, Fridays, and Saturdays, they would have sort of like a revival, and people would be singing, and dancing, and praying, and whatever they do at a revival.

And the main drag of the midway-I call it the midway-was on each side of the road. . . . and the dust would be knee-deep out there. People would be walking, and singing, and happy and buying all kinds of little pinwheels. Yeah, they had cotton candy at that time, popcorn, soda pops, ices, anything you wanted. ...

And all the neighborhood people would come in; people from out of town would come in. Only thing different [from today's powwow] was that they weren't dressed in regalia, and they weren't doing Native dances. There was story-telling going on. People had tobacco there. ... People camped out there. I remember my grandmother, when I was young, would go out, and my granddaddy'd go out and set up an arbor, a tent or something, and they would be cooking under those things. People would come, just like they do to a powwow. ... As far as I'm concerned that's what it was. It was a gathering of people, and that's what a powwow is, nothing more than a gathering. (1997; see Smith [1990:26] on similar events in Lumbee territory.)

In short, church-centered community events anticipated critical features of the powwow-sharing food, assembling and celebrating a community partially dispersed by the need to find work, a comfortable overlap of 
the sacred and secular. When one of the two small churches serving the Occaneechi gradually lost its Indian character, these Associations' value as specifically Occaneechi events lessened, and the demand for a new sort of community event grew.

Powwows answering this and related needs accumulated in the midAtlantic states slowly at first, then increasingly rapidly. Most of the regular annual powwows occurring in 1995-98 in the Piedmont and Coastal Plains of the Carolinas and Virginia are mapped in Figure 1 and briefly described in Table 1 . The numbering reflects when they customarily take place. Thus, the Haliwa-Saponi powwow, although the first founded, is " $\#$ " because its date of the third weekend in April makes it the seventh mid-Atlantic powwow of the year. Other groups on the original state Commission, the Waccamaw-Sioux, Coharie, and Lumbee, had their first powwows in 1969 or 1970 (see \#30a, \#24, and \#29a in Figure 1 and Table 1). ${ }^{3}$ The urban intertribal organizations now on the Commission initiated powwows fairly soon after each organization was chartered: the Guilford Native American Association (Greensboro) in 1976 (charter 1975), the Cumberland County Association for Indian People (Fayetteville) in 1980 (charter 1973), and the Metrolina Native American Association (Charlotte) in 1983 (charter 1976) (powwows \#25,\#28, and \#27 in Figure 1 and Table 1 ). The many smaller communities then chimed in similarly, e.g., the Occaneechi-Saponi in 1984, following political mobilization in 1983. Powwows continued to enter the calendar, with the youngest intertribal organizations, college groups, taking the last available winter weekends for indoor events. ${ }^{4}$ Of the forty-seven annual powwows in the Carolinas and Virginia mapped in Figure 1, five came into being before 1980 , fourteen in 1980-89, and twenty-eight in the 1990s. Several listed are now defunct and marked as such; roughly as many commenced in 1998-99. I omit most of the dozens of annual "hobbyist" powwows-most put on by two Indian-run culture businesses-though these often look like tiny traditional powwows to the outsider audience.

The powwow arrived in North Carolina as a mature package, and North Carolina powwows continue to match the national model in broad outline, though often not in details. Indians visiting from elsewhere can feel immediately at home in the dance circle, which is surrounded by a few ranks of chairs (the inner row for dancers only), some space to walk, a circle of vendors of Indian handicrafts and of food, and parking that may include a camping area. The cast of participants will also be quite familiar: one or several drums ("drum" meaning both the large instrument and the ensemble of a few to over a dozen men striking it), an emcee explaining and pacing the event (see Gelo 1999), an arena director keeping things and people where they ought to be, and from a dozen to over a hundred dancers. The older mid-Atlantic powwows are the largest and the most similar to Plains events. But older and younger, larger and smaller local powwows 
Figure 1. Locations of Annual Powwows in Piedmont and Coastal Plains North Carolina, Virginia, and South Carolina in 1995-98.

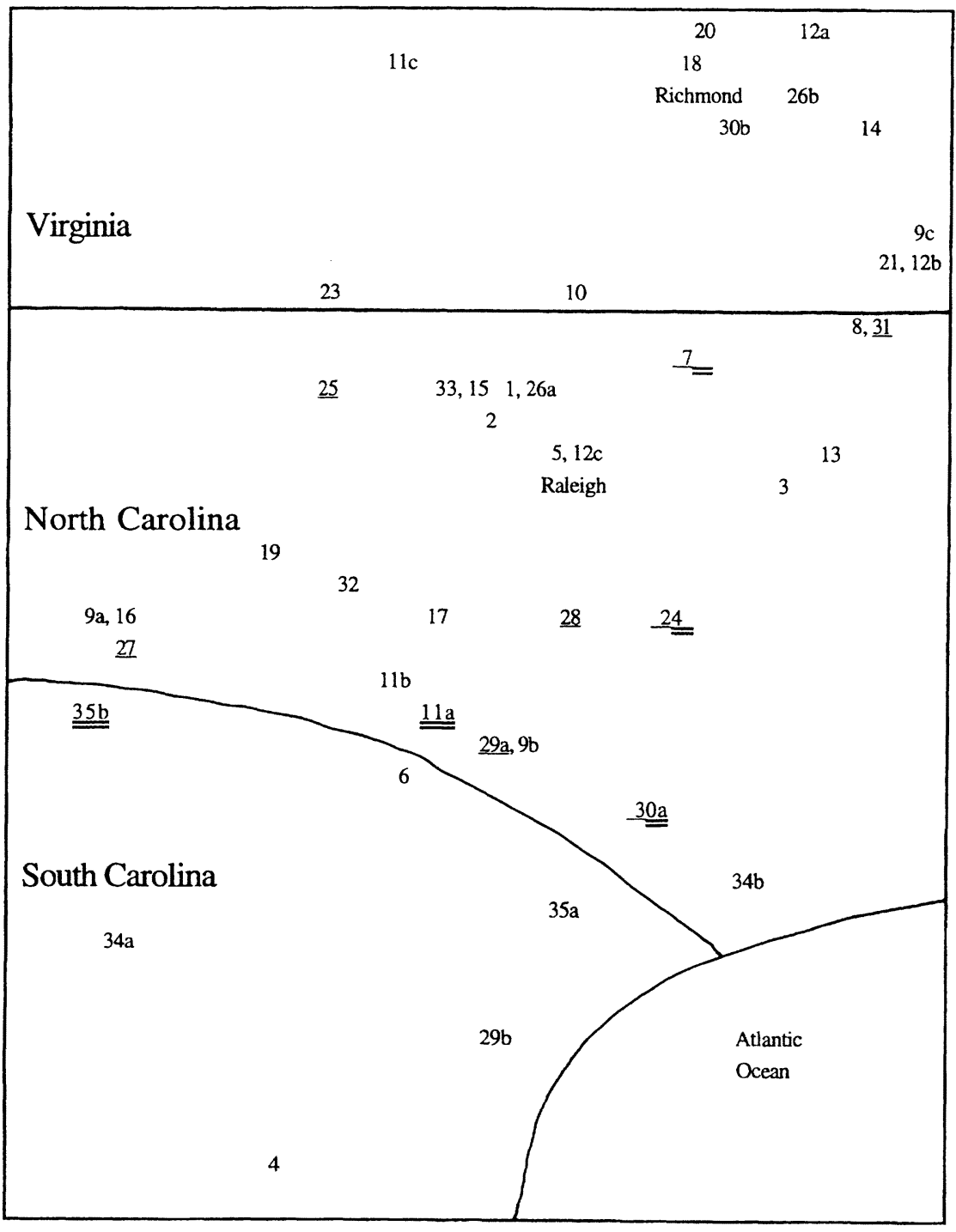

all follow modern general practice. Each afternoon or evening session of 3-4 hours begins with a grand entry (a parade led by a color guard, followed by all dancers grouped by gender, regalia type, and age). The most solemn part of the event follows, a flag song and a veterans' dance. Next come intertribal dances-for all who were in the grand entry-and between 


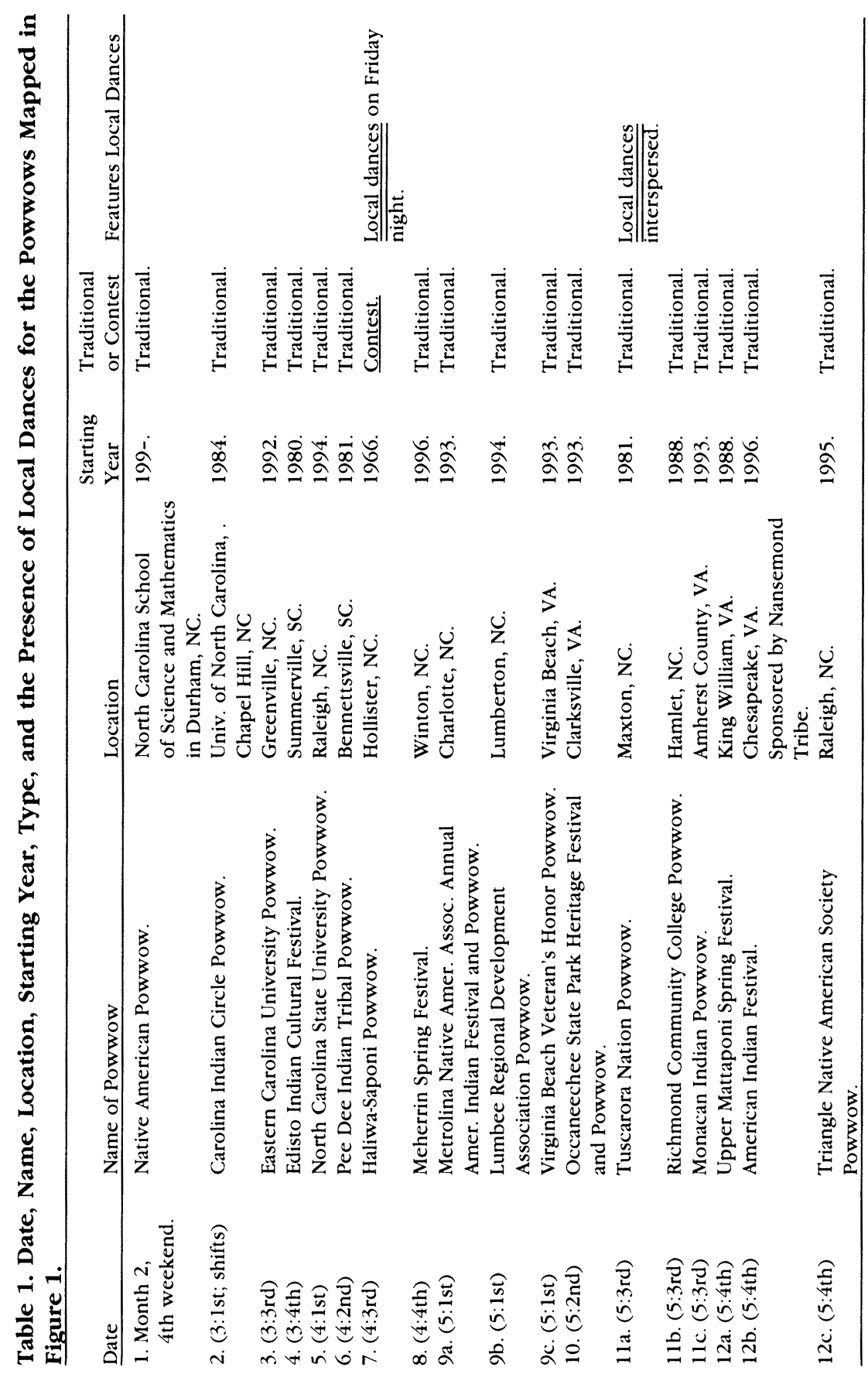




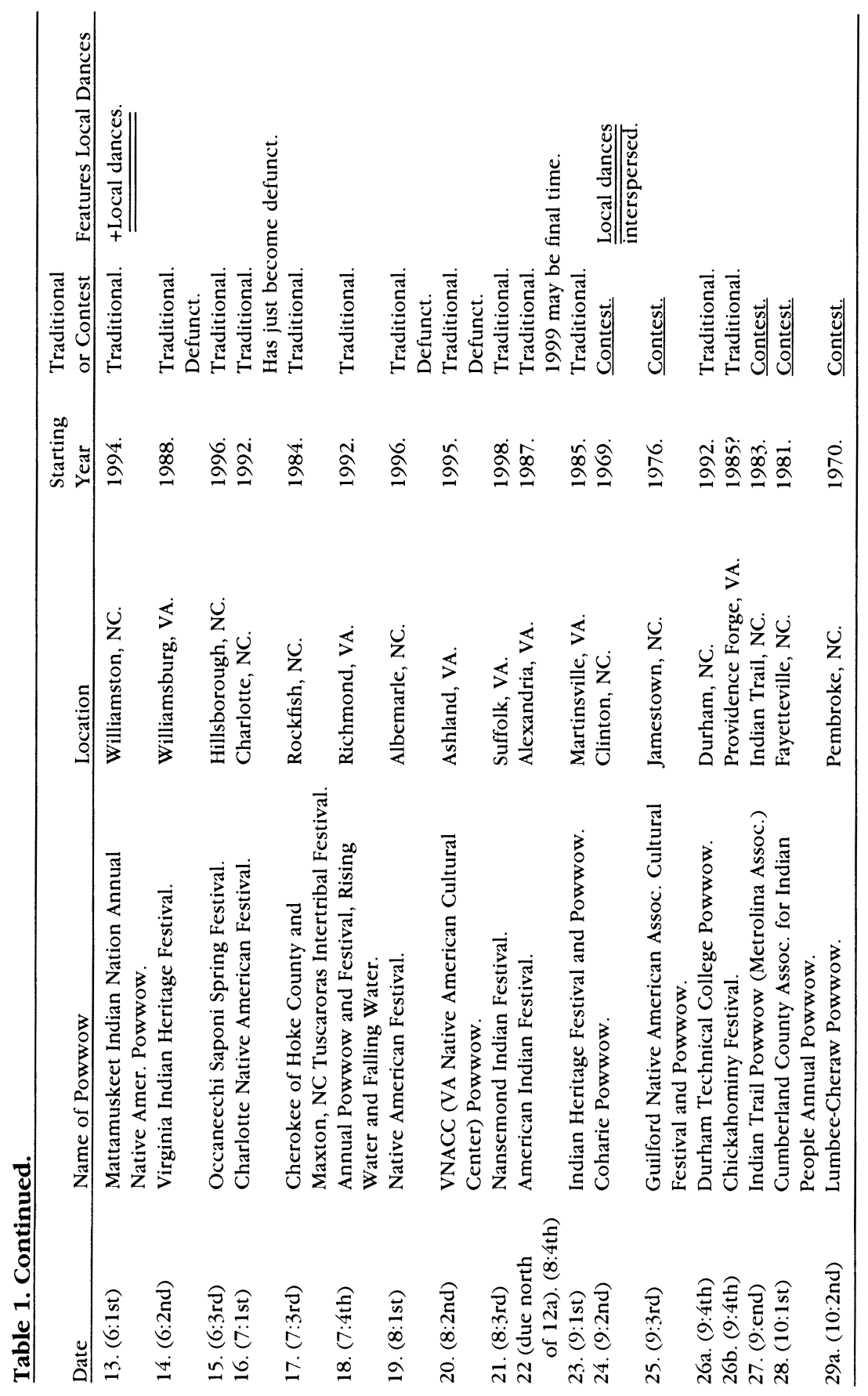




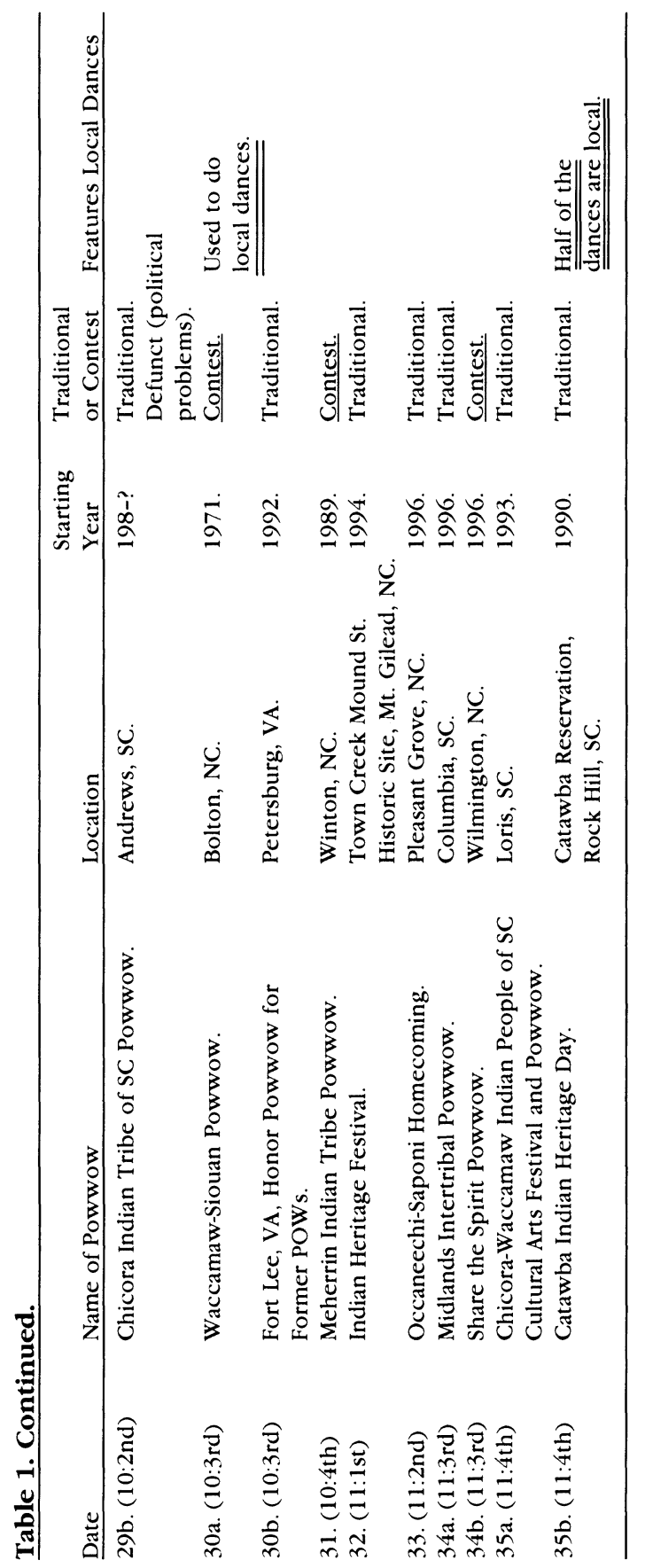


these, in no particular order, dances by category (for the men: traditional, grass, and fancy dances; for the women: traditional, jingle, and fancy/shawl) often further subdivided by age bracket. Other interspersed "specials," often specific to this region, are described below.

The older and larger North Carolina powwows, including that of the Haliwa-Saponi, are contests, although most local powwows, including those of the Occaneechi-Saponi, remain what participants call traditional. Many types of American festivals employ the contest format to impose order on and add suspense to long series of short songs or dances. The disadvantage of this for powwows is that they become less spiritual, according to numerous organizers. There tends to be less room for "specials" such as giveaways and social dances. But contests attract skilled dancers and thus larger crowds, making it easier to achieve a high energy level and for dancers to lose themselves in the attractive communion of flow. ${ }^{5}$ Nevertheless, North Carolina powwows remain relatively modest in size. That the Haliwa-Saponi contest powwow may have five drums attend makes it large in regional context. In contrast, in Alberta, where contest powwows are the norm, a small powwow has five drums, and a more typical one several dozen (Vargas-Cetina 1988:82, 94). Hartford, Connecticut's large contest powwow Schemitzun (Feast of Green Corn and Dance, put on by the Mashantucket Pequot) featured eight host drums and invited seventy more in 1997 (including just one from the Southeast, the Haliwa-Saponi "Stoney Creek").

With the powwow arrived a one-sentence description of its prehistory-"Indians have always danced in a circle around the drum," I heard repeatedly. A compact body of knowledge exploring and honoring the history of the various standard dances is regularly repeated for neophyte insiders and outsiders in conversation, by powwow emcees, and in lengthy printed programs. Typical phrasing celebrates cultural richness, noting recent historical detail while also insisting on an aura of antiquity. The Men's "Traditional Dance may be the original dance of the Indians of the Northern Plains." "Formerly the exclusive dance of princesses and ladies in leadership roles, the Ladies' Traditional Buckskin Dance is now open to all ladies." "Shawl Dancing ... is a comparatively new style, having been around only a couple of decades." "Originating among the tribes of Canada, the Jingle Dress Dance [while] relatively new to the Southern Plains . . . is an example of a very old dance which held a very spiritual meaning. ..." (all quotes in Haliwa-Saponi 1997:21-23, Guilford Native American Association 1995:18-21, and other powwow programs). While some North Carolina Indians know that the powwow as a ceremonial complex coalesced only in the 1940s, most consider the powwow traditional, both set in form and socially sanctioned for an unknown but presumably considerable length of time. 
The Plains complex of song, dance, and apparel traveled with some values attached. Toelken listed these, drawing on his experience in the Plains and Southwest: "circularity, time as an outgrowth of event (rather than vice versa) ... reciprocation, competition within culturally acceptable and meaningful contexts [and] the importance of the family unit ... [with events taking] place surrounded by the whole family and the tribe" (1991:154). Each of these values resonates to some degree with mid-Atlantic Indians, but two dominate. Simply put, the values which Indians in the tri-state area have long held most dear-and which have found new and vivid expression in the powwow - are overlapping ones, community (Toelken's "family" and "tribe") and sharing (Toelken's "reciprocation"). These communities exist as linked to geographical location and the natural world, nurture each generation in the extended family, and consist both of the "tribe" (at home and in diaspora) and of the broader Indian world (both through mutual support within this network of populations and as facing out towards the non-Indian world). ${ }^{6}$ And these Indians share work, sustenance and property, and share through valor. The ensuing intertwined examinations of how these values endure in these Indian populations and how they infuse local powwow culture illustrate how natural the powwow's transfer to this region has been.

The community most obviously celebrated at North Carolina powwows is that of all Indians. In the mid-Atlantic states, Indian heritage was until recently best downplayed. Early in the nineteenth century, during the period that culminated in the Trail of Tears (1830s-50s, broadly understood), to advertise Indian identity was to court inclusion in that disastrous process of systematic expropriation and removal. After that immediate danger passed, prejudice and systematic mistreatment remained. Many North Carolina Indians now in their fifties or older were told as children to keep their Indian identity secret (as were many of their contemporaries elsewhere in the United States). There were plenty of other ways to explain skin tint. Occaneechi-Saponi Wanda Whitmore-Penner has been called "Samoan, Black, Hawaiian and Mexican" (Velliquette 1998:12). A neighbor of mine in North Carolina who had worked with John Jeffries once had vaguely thought that Jeffries was "Lebanese or something," and the Indians of Person County used to be routinely called "Cuban." At the time that the larger North Carolina Indian communities were collaborating to form the State Commission of Indian Affairs and each arranging their first powwows, smaller and more vulnerable communities remained "hidden in plain sight," as many North Carolina Indians phrase it. Groups' public reemergence as Indians came with their first powwows, and so can be tracked in Table 1.

Powwows reinforce respect and affection for place, for both nature and the human history of locations. When North Carolina Indian men over the 
age of thirty or so speak of their youths, it is fishing, hunting, and exploring specific wild areas that dominate the narrative. It was relatively easy to fish and hunt within walking distance of home just a generation ago, since most North Carolina Indian communities occupied land marginal for agriculture, land neighboring or hidden within thickets and creeks on the Piedmont or swamps on the Coastal Plains (Hazel 1985:27; Ross 1993, 1999). Today it is difficult to make a living running these same small farms, and most contiguous wild areas have been developed. Men lament what their children are missing. But a continued spiritual and nostalgic intimacy with nature comes out in the powwow within emcee remarks, in the furs and feathers so important in the regalia, and in many dances that imitate animals or hunting.

At the same time, precisely where powwows take place often honors community history. Much is made of the fact that the annual Haliwa-Saponi powwow is held on the tribal grounds, which include the old Indian school closed upon integration. The Occaneechi-Saponi have gained an unusually detailed knowledge of their own history while seeking state recognition. Of their three annual powwows, one (\#10 in Figure 1 and Table 1 ) is in the Virginia state park containing the reservoir that drowned the island that had been home to the Occaneechi in the 1650s (until their decimation in Bacon's Rebellion in 1676). A second one (\#15) marks their next home, an Occaneechi village within modern-day Hillsborough, North Carolina, a village visited by surveyor John Lawson in 1701 (recently exhumed by University of North Carolina archaeologists, and being reconstructed as an open-air museum today; 1951:53-54). Next came absorption into the Saponi confederation and a series of alliances, migrations, and dispersals. In the 1780 s, the group now known as the Occaneechi-Saponi settled not far from Hillsborough in Pleasant Grove, which became home of their two churches and an elementary school their children attended-their third annual powwow is at that school (\#33). ${ }^{7}$ Powwows do help level the playing field between large and small Indian communities. Since many participants come from neighboring Indian groups, a small community like the Occaneechi-Saponi needs just a handful of deeply committed organizers to put on a powwow as convincing as that of a larger, state-recognized tribe like the Haliwa-Saponi.

Powwows celebrate the "close-knit-ness" (Watson 1997) of Indian family life: each age group in the community is served in some way. Powwow emcees single out the oldest and youngest present for praise. They regularly mention the debt owed the elders for their wisdom. (Ubiquitous formulas such as "the Native people have always respected their elders" implicitly criticize general American culture, just as does the equally common "Indians never shunned their veterans"). Toddlers have their own moment 
to dance. These "Tiny Tots" may or may not move their feet much out in the arena, but their regalia are lovingly crafted, they receive ardent and prolonged applause, and they hear emcees describe them weekend after weekend as "our future leaders." As they grow older, the powwow helps them craft good self-images through group reinforcement, and provides a wholesome and safe environment for playing, socializing, and eventually courting. Specific perils facing youths beginning to make their own decisions are dealt with openly. Flyers for events and emcee admonishments proscribe drugs and alcohol, ${ }^{8}$ and a youth choir that performs briefly at many North Carolina powwows bears its message in its name, "Love Can Wait." Powwows provide adults a focus for self-esteem and intellectual engagement that may be lacking in the work week (low educational levels and reluctance to relocate often result in hum-drum jobs). And the spirituality of powwows reinforces rather than replaces the staunch Protestant faith that most of these Indians have. Early during each session of a powwow, a pastor of Indian heritage intones a blessing consonant with both Christian and Indian beliefs, ${ }^{9}$ just as churches in this region with substantially Indian congregations seek out that common ground.

The powwow system helps North Carolina Indians cope with the modern forces that work to disperse rural communities throughout the country. The shrinking of never-generous economic opportunities at home presents many Indians with a stark choice between staying put in their nurturing communities and making a decent living. Each local powwow, by representing traditional Indian and rural values and through celebrating the history of given communities, asserts the primacy of spiritual health and community life over material improvement. And while some rural Indians attend only their own community's powwow(s), others refocus their lives away from the work week to fulfilling weekends by charting their own powwow circuits from among the dozens of events within a few hours' drive. Nevertheless, many Indians have had to relocate. Powwows help these emigrants preserve a sense of community in two ways. First, powwows reinforce (or replace) the longstanding custom of holding on to home church membership with one of routinely returning home for the community powwow (Gaillard 1971:6). Some home-comers will dance, but many more visit with relatives and friends in the audience, giving and receiving news updates and gossip until their throats are raw. Second, the new urban communities made up of these rural emigrants will mark and buttress Indian identity and values by putting on their own powwows. Of the events described in Figure 1 and Table 1, the urban and intertribal ones (most for laborers, but a growing number for students) slightly outnumber the rural and tribal ones, both within North Carolina and in the complete mid-Atlantic system. 
Powwows are the main tool North Carolina Indians have for defining their collective identity to outsiders, many of whom arrive at these events knowing precious little about contemporary Native America. Powwows intrigue outsiders by displaying the most positive and colorful aspects of modern Indian life. Audience members are invited to take the measure of Indian communities flourishing among them, and to empathize with Indian values, but not to become Indians. They may videotape most but not the most sacred segments of the event, and will be warmly invited to join specific dances. They can purchase furs, jewelry, and ornaments from the Indian vendors, but should not return with these stitched into regalia, expecting to join the dance circle. In short, Indians use powwows to encourage the surrounding world to respect both the nature and the boundaries of their communities.

Even before the music and dancing begin, the range of what these Indians wear bridges the gap between fantasy and daily life. First, dance outfits of Plains derivation are both spectacular and familiar. Yes, living Indians can be visually akin to those seen on TV, which represent a romantic and generalized past to the neophyte. ${ }^{10}$ Second, in the last decade, a fair number of North Carolina Indians have opted for regional historic garb, with fewer feathers than in the received powwow, and often with cloth replacing leather. Not all Indians share the same history. (The growing use of locally-derived regalia does not reflect a devaluing of Plains regalia, but rather an array of choices to add to those available within the conventions of Plains outfits.) Third, the young men at the drums wear casual clothes often including shirts and caps bearing sports logos. These Indians share our enthusiasms. Last, mothers sitting in the dance circle in street clothes as they dress their kids in regalia obviously shop at the same local stores that many in the audience patronize. These Indians are our neighbors.

The powwow arrived as a shared cultural complex, shared among individuals, among Indian communities, and between participants and their mixed audiences. While Carolina Indians know and employ the term "PanIndian," they often cite it as an outsiders' word for powwow culture, a rubric with some utility but not quite on target. "Pan" means "shared" as "in common, overarching," but neglects process, i.e., giving and accepting. Insiders prefer to describe powwows as "intertribal" and as "shared." And, while the powwow is by definition not tribe specific (Vargas-Cetina 1988:23), i.e., it is intertribal in both origin and purpose, it must remain a shared event in the mid-Atlantic Piedmont and Coastal Plains, since few communities produce enough active dancers and musicians to support a festive powwow. The larger rural communities and urban organizationsapart from the Lumbee, this means groups with one thousand to three thousand members-must attract dancers and musicians from elsewhere to 
create events that are big and full of energy. The Haliwa-Saponi would have two drums at their powwow rather than a half dozen if they employed only their own. The much smaller Occaneechi-Saponi can send a few wonderful dancers and a flutist and story teller to others' events, and tribal Chairperson John Jeffries demonstrates traditional weapons at many powwows and is the busiest emcee I know, ${ }^{11}$ but there is no Occaneechi-Saponi drum. Without the routine sharing of participants, the small Indian communities in the tri-state area-that is, most of them-could not mount powwows.

Much more is shared at powwows than their arrangement. For instance, while the traditional pooling of labor to bring in each family's crops and the shared meals punctuating this long process have become casualties of the modernization of farming, such feasts and those of the fundamentalist "Associations" resonate in feasts that powwow organizers mount for participants. The food served illustrates this continuity. It is southern rural fare, often with a regional focus, a roast pig in the Piedmont or seafood stews nearer the coast. In contrast, the vendors serving the audience supplement hotdogs and fries with Pan-Indian fare such as buffalo burgers, "Indian tacos" (ground beef and salad on fry bread) and the occasional venison stew or bear "steak-um." They market pan-festival and Pan-Indian food while the Indian dancers and musicians share a big church supper with local or regional overtones.

The honoring of veterans at powwows has to do as much with sharing as with valor. Yes, serving in the military echoes the old warrior societies (certainly applicable on the Plains, somewhat so here), and the military environment, though highly structured in some ways, is refreshingly egalitarian in others, notably in minimizing segregation and displays of racial prejudice. And Indian soldiers may travel extensively and have new experiences without feeling disloyal to their homes or families. Many Southeastern Indians enlist, as is true of Indians nationwide (Hirschfelder and Kreipe de Montaño 1993:227-36), but few aspire to a career in the military. The experience is primarily a rite of passage, a pilgrimage during which participants offer to share the ultimate, to give up their lives for the country that includes their community. Honoring them for the rest of their lives at powwows neither endorses nor criticizes American wars, and whether a given individual endured combat is not central. The magnificence of the personal offer to share that each soldier made simply by enlisting is what matters.

Last, these powwows explicitly involve the sharing of property. Pooling resources of all kinds has been important in these economically marginal communities for centuries, and extended families who once farmed together often mitigate having been forced off the land by reassembling at the same factory (Beasley 1981:39). They share money and goods both 
through necessity and preference. One reason that the components of some dance outfits (regalia) may not seem fully coordinated in terms of color or texture is that their value accrues less from appearance than history: they were gifts. And many events feature "giveaways," during which, for instance, a paid head dancer may ritually honor individuals by awarding them items ranging from blankets to apples, gifts together costing far more than the dancer was paid. (This can take awhile, and is one of few times that acts expressing values important to the participants can leave audiences restless.) Last, youngsters heading off to school or crucial but unpaid performers (for instance, a drum that has traveled a long distance) may benefit from a "blanket dance," during which money is collected on a blanket in the arena. Just as in daily life, in both ancient and more recent times, achievement is measured by how much and how well one has helped others, surpluses are distributed rather than accumulated, and to have is to share.

The core insiders and visitors, the people most committed to communicating or learning about culture, constitute groups too small to sustain such events year after year by themselves. To succeed, powwows must be fun, must make cultural diplomacy entertaining to both presenters and visitors, and the cultural materials chosen for presentation must be apt for the festival setting.

In North Carolina, audiences (that is, the constituencies apart from resident and returning Indians) are mixed in several ways. They are racially inclusive, more so than audiences at any other festivals based on ethnicity or race. Also, Brownell argues that "small farmers, recent rural immigrants to the city, and a large number of urban intellectuals" have in common that they are the "psychologically least secure in the rapidly changing world of 20th-century America," and that they therefore have "persisted in their preference for a non-urban environment" (1971:584). Many visitors to powwows fit this description in that they expect for powwows to anchor sensory offerings in an exotic and timeless solace. That is, the nonIndian local citizens who dominate many audiences are seizing an opportunity to be cultural tourists without leaving home. Indians present a nonthreatening and, these days, glamorous ethnicity. Most interestingly, many visitors to North Carolina powwows combine the typically southern affection for "everything historical-we go to Civil War reenactments too" with a common working class and southern way of linking interests in history and in family through pursuing genealogy. After consulting family Bibles and doing research at local historical societies, countless North Carolina audience members-both white and black-proudly cite an ancestor or two 
said to have been Cherokee or simply "Indian" (the name of the group often had been forgotten; in any case, the lifespan of the ancestor in question would have antedated most contemporary names of tribes).

For Indians, when the novelty that powwows initially offer evaporates, it yields to a progressively more nuanced enjoyment of the considerableand growing-variation in powwow format, in regalia, and in music and dance. Holding the performers' attention really matters-while audience members usually stay for a few hours at most, most participants commit for entire weekends. I will discuss in turn the richness of the basic powwow complex of music and dance, the current dynamics of change in that basic system, and the expansion of the array of powwow attractions to incorporate local elements and local syntheses in mid-Atlantic powwows.

Even the most schematic view of powwow music and dance reveals rich variety. For both men and women, the dance whose regalia and steps are called "traditional" is the most common in North Carolina. Next most frequent is the fancy dance (men) and fancy shawl dance (women), both physically taxing even for the fit teenagers and young adults who dominate these categories. Male fancy dancers are willing to drive farther than do others in order to focus on contest powwows: their winnings help finance the extra travel. In third position are dances intermediate in the level of energy required, and with very distinctive regalia, the grass dance (men) and jingle dress dance (women). In all of these dances, convention governs both regalia and dance steps, but leaves lots of room for individual expression: dancers perform simultaneously rather than in ensemble. Here, the main solo display dance imported from the Plains, the spectacular hoop dance, joins honor dances, blanket dances, and social dances as relief from the basic dance categories. Powwows in this region may also feature one or several non-dance displays: story-telling, flute playing, and demonstrations of crafts, wilderness survival skills, or primitive weapons. These nondanced "specials," more common here than in Plains powwows, possess several virtues: they recall southeastern tribal fairs, they educate, and they offer relief to over-extended dancers and singers at the relatively small powwows of this regional system. ${ }^{12}$

In Plains Indian music, the Northern and Southern styles are most transparently characterized by tessitura, the Southern style being lower-pitched, and therefore with more importance accorded occasional reinforcement at the octave by women standing behind the drummers (Browner 2000 explores customary differences in form). In both styles, the standard song form-strophic with incomplete repetition within each strophe or "pushup" - still allows variety in phrase length and rhythmic relationships. And the associated terraced descending melodic contours still differ significantly from song to song, though these sources of variety may escape audiences. 
But the energy and attractiveness of the music to audiences comes less from the elements of form and melody than from rhythm and timbre. The steady drum beat (generally accelerating slowly during the course of a song, and with accented beats in standard locations for each style) sets the tempo for the voices, but the notes of the song may not start with or fall exactly in the middle of a drum beat (compare Example 1, a Southern-style song made in North Carolina, with the songs transcribed in Browner 2000). This is not to say that the melody floats freely - the tie with the drum beat is absolutely firm, although the knots can be well-hidden (Powers 1990:33). Rather than discrete moments of syncopation, we hear an incessant tug of war between drum and song, a vibrant rhythmic fabric. At the same time, the deep power of the sound of the drum and effortful, raw vocal timbres impart incredible energy. In a mild paradox, rhythm and timbre strike many auditors as quite exotic, though it is precisely these elements that make powwow music accessible to the general run of American listeners. Powwow music is just striking enough; it surprises without alienating.

There are far more Northern than Southern drums in North Carolina. The spectacular high-pitched sound of Northern singing impresses beginners and echoes the pop culture picture of Indian music initiated in Wild West shows at the turn of the century and still passed along to all Americans through the media. As a minor benefit, Northern tunes tend to be easier: these are more likely than Southern ones to stick to vocables in song texts, and have fewer melodic subtleties. ${ }^{13}$ But North Carolina powwow arrangers may supplement the dominant Northern sound by seeking out or at least welcoming a Southern drum: founders of the young intertribal drum "Southern Sun" (formed in 1994) chose Southern style partly because they suspected (correctly) that this might inspire invitations to powwows (Liles 1997). Preferring the bolder profile of the Northern sound illustrates intensification through selection, ${ }^{14}$ while adding the Southern sound to a powwow heightens the musical complexity of the total event. Further buttressing this general trend towards intensification, yet undermining the historic distinctiveness of Northern style, Indian song makers in both styles now write more songs that trace increasingly involved contours. Also, more drums are performing "word songs," in which the main vocal burden of vocables yields to a phrase or two of words in the repetition part of the incomplete repetition form. Although these songs are harder to learn, and thus to share between drums or for pickup groups to perform, the added difficulty presents a challenge welcomed by many singers and impresses judges at contest powwows.

When North Carolina Indians join in the national trend to make more word songs, they want to mark tribal identity by using their own languages. This isn't yet common-the Piedmont and Coastal communities in a 
position to recover their historic languages are in the earlier stages of doing so-but the song-makers who can employ these languages consider the effort worthwhile. In the excellent Northern-style drum Stoney Creek, most of the members of which are Haliwa-Saponi, Marty Richardson writes lyrics in Tutelo, the Saponi language, while a Lumbee member writes in Cheraw, which is considered a historic Lumbee language. Such songs travel well, since the musical style remains that shared from the Plains.

Example 1 is a transcription of a sample North Carolina Indian song, made for powwow use by members of the intertribal drum Southern Sun. Since this drum is based in the Chapel Hill-Durham axis, just a dozen miles from Hillsborough, it participates in many Occaneechi-Saponi events. It is

Example 1. Tuscarora Nation of North Carolina Flag Song (perf. Joe Liles, 1997).
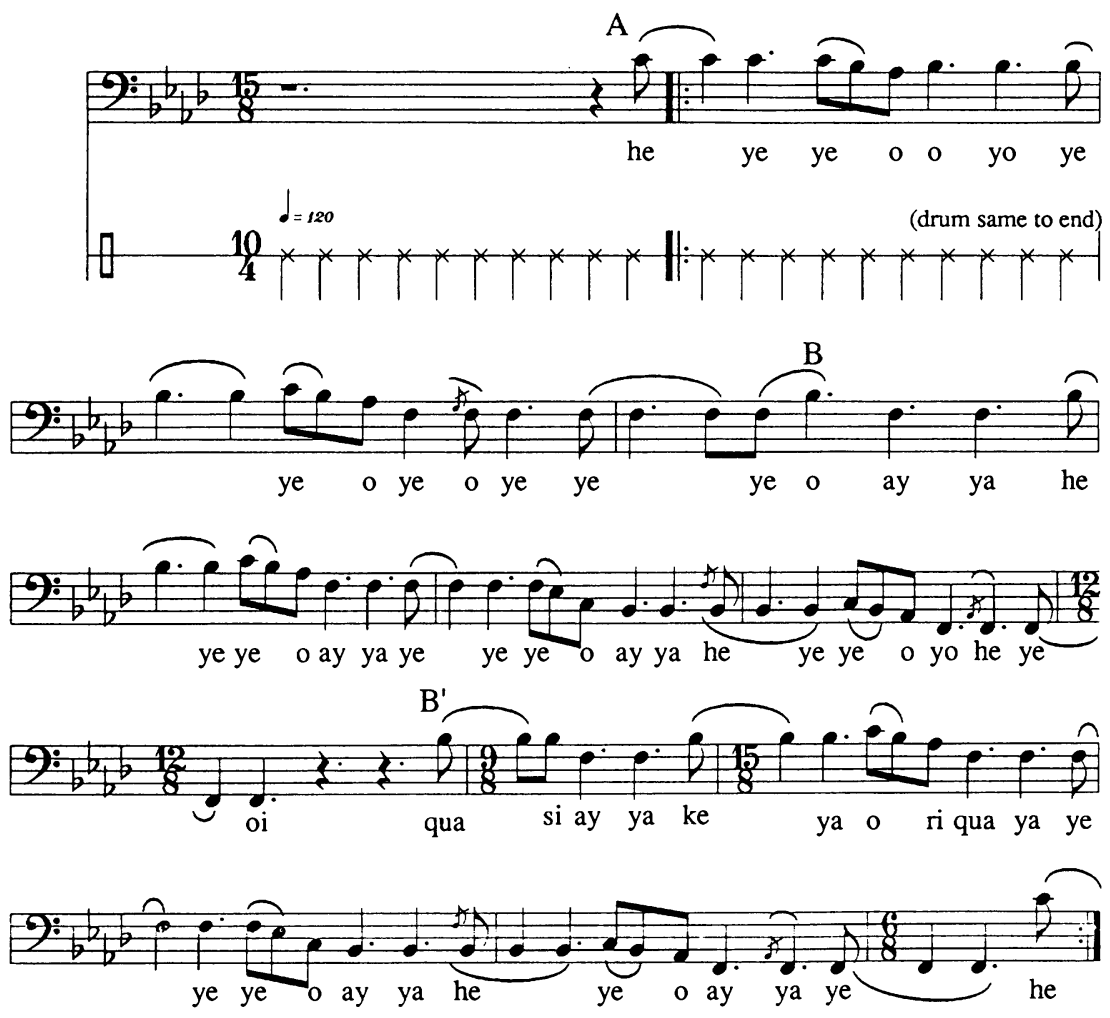

Note: Time signatures and barring meant

to show relationship of drum beat and voice, not to suggest adding weight to any beat. 
expected that each tribe will have a flag song, and that this will be a word song. Derek Lowry, a Tuscarora member of the drum, wrote the text, which literally means "This is our flag: it is good" (in Ex. 1, at B' up to the last syllable on that staff, preceded and followed by Plains vocables in typical fashion). As in most such lyrics, words are few but meaning resonates deeply. To recover the Tuscarora language, North Carolina Tuscaroras are learning from a handful of New York Tuscarora elders. There was no traditional Tuscarora word for flag, but these elders had seen flags draped across the caskets of soldiers killed in Vietnam, and this powerful image suggested expanding the meaning of their word for blanket, "oriquaya," to include flag. Lowry also told me that he wrote the contour of the opening phrase to remind him of longhouse (thus Eastern Woodlands) tunes (1999). The total musical form fits Plains style, so both tune and text have the virtue of being at once local and general.

The other main way to incorporate local music and dance in North Carolina powwow music is to perform songs associated with a specific community or with the Woodlands region. The powwows that do this are marked with a wavy underline in Figure 1 and Table 1 . In fact, the first few powwows put on by the Haliwa-Saponi drew quite heavily on such songs. Then, as it became easier to attract Plains-type drums (and eventually to nurture these) Plains powwow music came to dominate this and all North Carolina powwows. At the very successful Haliwa-Saponi powwow, the contest format now leaves no room on Saturday or Sunday for local music, but Friday night still features a handful of local dances, particularly the animal dances that had been so important here. Of the half-dozen such dances that regularly are scheduled at this powwow, the Robin Dance is a crowd favorite (transcribed in Example 2; for other Haliwa-Saponi dances see Burton 1993:54-59).

The many ways that modern performances of such tunes contrast with Plains music makes these Eastern Woodlands songs relatively easy on both insiders' and outsiders' ears. Voices are much more relaxed than in Plains singing (particularly than in the favored Northern Plains style), and the accompanying rattle (or, in some dances, sticks or hand drum) has a timbre less imposing than that of the large Plains-type drum. Melodies often trace arches, more familiar to visitors than the descending terraced contours of Plains songs. While the pitches employed match the pentatonic array illustrated in the Plains-sounding tune given in Example 1, the Robin Dance opens by outlining a major chord, then continues to sound less truly pentatonic than major, albeit not getting around to employing the fourth or seventh degrees. And the rhythms are quite accessible. The Plains tension between drum beat and vocal line yields here to simple support of the vocal line, with both melody and accompaniment in straightforward triplets. The 
Example 2. Robin Dance (perf. Dalton Lynch, 1997).
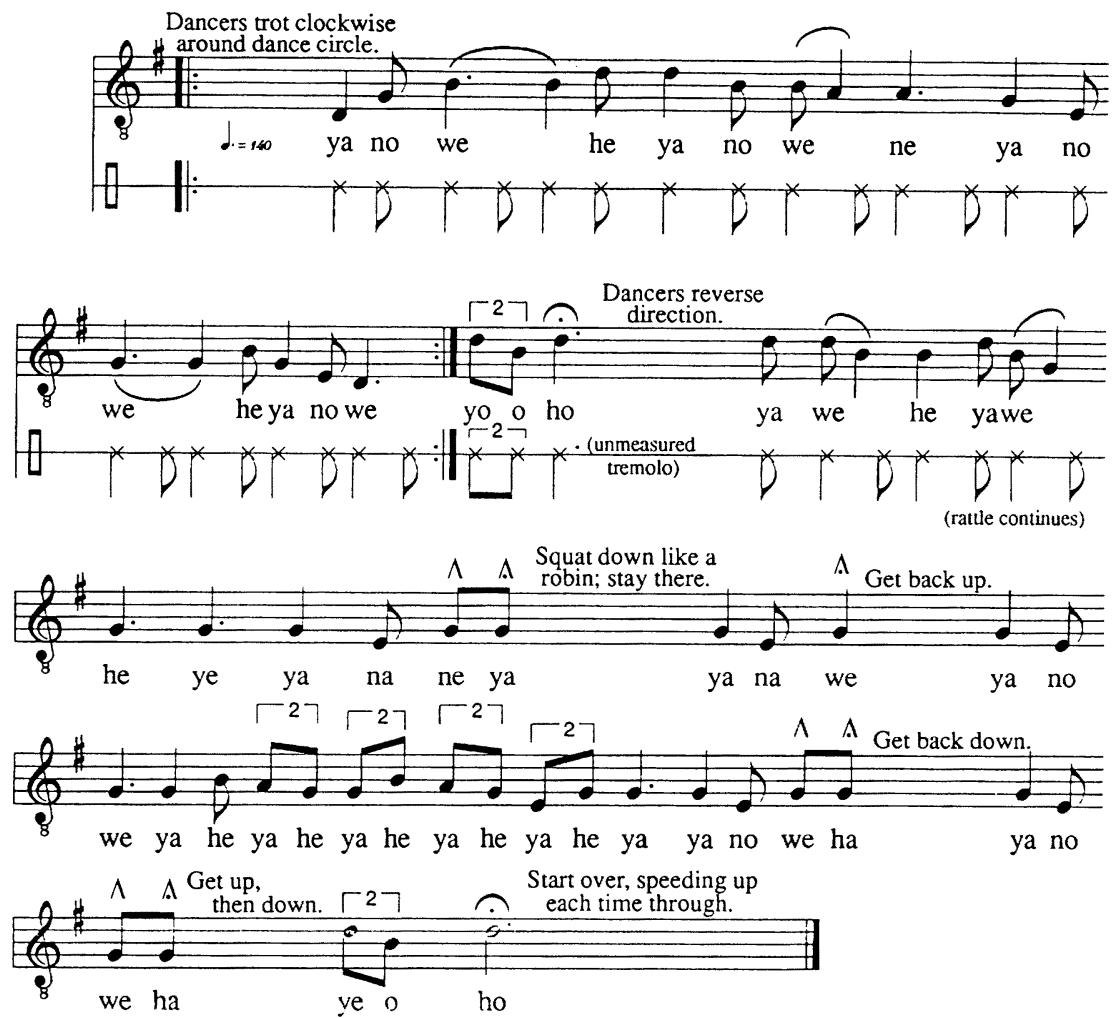

general feel is a bit more metric, although shifting between loose groups of three and four beats, and though frequently interrupted by pauses during which the dance changes direction or the dancers squat or rise.

I transcribed the Haliwa-Saponi Robin Dance during an afternoon with Dalton Lynch, who both knows this local repertoire well and often serves as head judge at the community powwow (1997). He often paused to insert dance instructions. While this was an elicited performance, the dance is taught anew at each annual powwow. After a time or two through the sequence of steps, the narration stops but the pauses remain, filled with a rattle tremolo and humorous suspense ("When are we going to get to stand up?"). Each pass through the sequence is faster, and dancers get tired, err, and laugh. The atmosphere recalls that of the social dances that punctuate most powwows, particularly that of the ubiquitous snake dance, a followthe-leader number in which dancers constitute the snake by holding hands, with the head dancer leading the group into sinuous contours the increas- 
ing entanglement of which can lead to hilarity. The Robin Dance does mark local identity, ${ }^{15}$ but it, like the Pan-Indian snake dance, functions primarily as a solemnity-relieving novelty. Indeed, at some powwows (see \#11a, \#18, and \#24), Woodlands dances like this one are not relegated to Friday night, but instead enter the general powwow as "specials" in the same broad change-of-pace niche as the snake dance, two-step, and 49.

While most dances at the powwow mesh spirituality and conviviality, with these local animal dances the ratio shifts in favor of fun. In a complementary function, the regional stomp dance projects more seriousness than do either the other local dances or the intertribal dances from the Plains. One choice a group can make is to take especially spiritual music out of public view - this is what the Eastern Band of Cherokee have done with their stomp dances. Their powwows are quite large and attract more casual and non-local tourists than do powwows in the Piedmont and Coastal Plains; tourists fuel to the "most-visited" boast of Smoky Mountains National Park (see Gattuso 1990:309-11). The stomp dance, fragile before the powwow arrived, has been revitalized as part of renewed involvement with regional culture. This points towards the center of the country in two ways, drawing on the Oklahoma Cherokee for music to supplement the modest amount retained by the Eastern Cherokee, but doing so only after a critical mass of interested Eastern Cherokee had been assembled under the impetus of the powwow (Swimmer 1997).

The Eastern Cherokee now arrange stomp dance evenings as intimate affairs for themselves and invited visitors only. In terms of public versus private use, the Haliwa-Saponi Robin Dance and other Woodlands dances mark the other end of a continuum, since this local repertoire has become part of their powwow. The Occaneechi-Saponi are charting a middle course as they assemble a non-powwow repertoire-some songs are private (including their stomp dances) and others see ceremonial use in public contexts. Lawrence Dunmore, former tribal chairperson, spearheads this effort. He has been given songs by a member of a community historically linked with his, Canada's Cayuga, which absorbed parts of the Saponi nation during the eighteenth century. Dunmore shared one of those songs at the dedication ceremonies for the Occaneechi village being reconstructed on the 18th-century Hillsborough site. His delivery of this simple song was very moving-even though only he understood the words. The effective message was that a specifically tribal ceremony could be marked with tribal music.

Dunmore also makes songs himself and in collaboration with others. He translated into Tutelo the text of Mahkji, recorded on CD by Ulali (n.d.). One member of that virtuosic close-harmony female trio, Tuscarora (Northern) Pura Fe Crescioni, moved to North Carolina, sparked the North Caro- 
lina hand drum revival, and participates in some Occaneechi events, though her involvement has been limited by Ulali's cramped concert and festival schedule. Mahkji has become both one of Ulali's signature tunes and a staple of the emerging Occaneechi repertoire. Recent performances of it included one by Ulali in Italy-some crowd members knew the song well enough to sing along - and one by John Jeffries at the dedication of a park on Occaneechi Mountain, which he can see from his front porch (L. Jeffries 1999).

The way the Occaneechi are building a local repertory today, through modern gifts of songs from groups with whom they share a past as well as through creativity in which sharing looms large, is not so different from how the Haliwa-Saponi local repertoire came together. For instance, the HaliwaSaponi Alligator Dance came from the Seminole, from Florida, whereas their Welcome Dance came from the Chickahominy, from across the state line in Virginia (Lynch 1997). Is it reaching too far to consider this process parallel to the more widespread sharing of powwow music? Why does it matter that the Yahi shared music from other tribes (Nettl 1965:211), i.e., that this practice seems to have been as normal in the simplest tribal repertoires as in large and complex repertoires such as that of the Blackfoot and Flathead (Nettl 1989:6 and Merriam 1967:21)? Did these routine adoptions clarify boundaries of community identity by allowing close-up savoring of differences in song styles? Or might this practice indicate that a longtime function of music among Indians has been to articulate and reinforce the value of sharing between communities?

It would be easy to dismiss the powwow as formed in the Plains and received elsewhere as a matrix of "invented traditions," but better to seek more nuance. As we revisit American traditions at the end of the twentieth century, each shows evidence of a patina of nostalgia, of a new battery of ideology, of willful selection from the known past rather than replication of a past the continuity of which was mythical anyway. But each case works differently. For instance, in North Carolina fiddling, when rural whites honor the letter of the past by performing old tunes which bear unimpeachable local credentials and employ historically-informed performance practice, this fits into the modern ideological framework of a nativistic revival. They play old music for very new reasons (Goertzen 1996). In the case of North Carolina powwows, the opposite holds. Music and dance that is not native to North Carolina, and rather young in many details, embodies ideology with local and ancient roots. New music and dance is performed for very old reasons.

In 1955, James Howard, in an early and influential approach to Pan- 
Indianism, defined it as "the process by which sociocultural entities such as the Seneca, Delaware, Creek, Yuchi, Ponca, and Comanche are losing their tribal distinctiveness and in its place are developing a nontribal 'Indian' culture" (1955:215). Much later, William Powers troped that "tribalism, a tendency toward maintaining tribal distinction, becomes indicative of traditional cultural identity and continuity in culture, while intertribalism, the tendency toward exchanging cultural traits between tribes and between the Euroamerican society, becomes indicative of modernity, social identity, and cultural change" (1990:11). These generalizations make some sense in the abstract, but seem an awkward fit on the Plains and certainly don't work for North Carolina. In the return to widespread cultivation of public expressive culture in this region, powwow music and dance often remain the only Indian music and dance. Further, where powwow culture now exists alongside regionally derived song and dance, the powwow usually preceded (and stimulated) the revival of that specifically tribal culture. ${ }^{16}$ And the powwow marked a critical juncture in many communities' histories, the time of reemergence into public view. John Jeffries wears Woodlandsstyle regalia today, but is proud to have his older set of Plains-style regalia in the tribal museum in Clarksville, Virginia because it was with the powwow that "they first witnessed the Occaneechi people coming back" (1997).

The powwow was not "borrowed" by mid-Atlantic Indian communities; it was given to them, and thus belongs not to some distant or overarching entity, but rather to each Indian group simultaneously. It is not PanIndian, but rather community-specific many times over. That this gift came to so many groups allows them to perform their shared values as embodied in shared materials and in shared events, valuable both in terms of ideology and practicality in these small populations. When communities have retained or now seek out a tribal or pan-Woodlands repertoire, this music complements powwow music on a small scale. The Haliwa-Saponi powwow changed during early years so that the function of the local repertoire shrunk, while the Occaneechi-Saponi local repertoire grew. The balance between repertoire types converged, attaining in both cases an equilibrium between prominent Plains-style multitribal music and a modest but important array of local songs and dances. At the same time, some North Carolina Indian song-makers portray precisely this balance of national and local within individual songs that never contradict Plains style, but have texts in their own languages, and may evoke Woodlands music subtly, as in the Tuscarora Flag Song.

In a study of the meanings of powwows among coastal North Carolina's Waccamaw-Sioux, Lerch and Bullers found a direct correlation between concern with traditional values and cultivation of that community's pow- 
wow (1996). My consultants from various North Carolina Indian populations were unwilling to rank powwow music and local music in terms of either traditionality or overall value to community identity. In any case, "tribe" is not originally an Indian concept, but rather an outsiders' caricature of group relationships in which variety and flux had long been the rule (Nagel 1996:xii; see Noyes 1995). The known history of each Piedmont and Coastal North Carolina Indian population is one of jeopardy, amalgamation, dispersal, new alliances, and movement: the multitribal ancestral stocks described for the Haliwa-Saponi and Occaneechi-Saponi are representative. Current long-term places of residence were fixed gradually, as whites inexorably painted Indian populations into corners, into refuge areas of less desirable land (Sider 1994:221-23). The idea of the tribe as a stable and bounded group has broad appeal: putative clarity and continuity of identity in the past implies the promise of those qualities being "recovered" in the future, offering succor in the unstable present. And these Indian communities are actually becoming "tribes" in the modern received sense because this model has practical appeal: federal and state governments want to know exactly to whom they should avoid providing services, and the communities who are designated as or wish to be called tribes desire coherence for any number of administrative reasons. But the mix of processes that have shaped and continue to shape regional Indian musical repertoires does not reflect the artificial clarity of the idea of the tribe, but rather parallels the muddy actual history of populations acting out a dialectic between focused identity and the incessant realignment required for survival.

Soon after learning in June of 1999 that the North Carolina Commission of Indian Affairs had again turned down the Occaneechi-Saponi petition for state recognition as a tribe, Occaneechi Chairperson John Jeffries formally invited each member of the Commission to the annual Occaneechi-Saponi powwow in Hillsborough, a gesture he has made repeatedly (Rochman 1999). I recently asked him to spell out its implications. Just as in song texts, a few words stand for much. He pointed out that the members of the Commission go to many powwows, and that legislators, chiefs of recognized tribes, and Native Americans from elsewhere in the U.S. come to the Occaneechi-Saponi powwow. In fact, he has heard that many of these visitors believe that this powwow is

one of the most traditional powwows they've been to. What we're saying is that we're trying to follow tradition. So what I'm telling the Commission is that 'we would like for you to come to see what we're doing. There's no way that 
you can make a true decision sitting back listening, especially when you need to visit the community ... Come to our festival. See our people. See what we are doing. Anybody can hold a powwow. Boy scouts can hold a powwow. NonIndians hold powwows. So come to our powwow and see what we are doing." (1999)

For both the members of the North Carolina Commission of Indian Affairs and for the Occaneechi-Saponi, Indian and tribal identity reach beyond the official criteria for state recognition, criteria that concern the past and that can be met, as legal matters must, through indisputable documentation. The most recent Occaneechi petition is in fact meticulous, and absolutely convincing to outsiders to the controversy who have studied it, including me. The Occaneechi have satisfied five (the minimum) or six of the eight official criteria-though not number seven, the only one concerning expressive culture. In fact, I doubt that any North Carolina Piedmont or Coastal Plains community could muster a convincing battery of "documented traditions" to do this. But while the critical mass of legends, songs, and so on has been lost, the values that imbued those cultural materials are alive and well in new garb, in many a powwow. This can't be proved in a legal sense, but really is what matters most. The Commission members have not been swayed by an unequivocal answering of the criteria set by themselves. They need to believe that the Occaneechi-Saponi are Indians in their hearts and as a community, and Jeffries feels that they would become convinced of this if they would witness the Occaneechi community articulating shared traditional Indian values in their powwow.

The News and Observer editor quoted at the beginning of this essay was myopic to decry the Occaneechi's putting on of powwows, though far from alone in finding fault with mid-Atlantic Indians' partaking in Indian culture originating in the Plains area (e.g., Sider 1994:245). But he was right to see these powwows as integral to how the Occaneechi have chosen to articulate community identity, as events to be considered in the same breath as state recognition. Returning to Turner's model of social drama, we can see that the Occaneechi want for the "ritual" realization of "redressive process," the powwow, to unclog the "legal-judicial" channel (1990:10). Mattern pointed out that "regardless of the philosophical and spiritual orientation of participants, the powwow represents for most people a place where differences can be set aside, at least temporarily, in favor of fellowship and unity" (1996:186). If the members of the North Carolina Commission of Indian Affairs do attend the Occaneechi-Saponi powwow, perhaps that happy state could be attained, a fresh start in negotiation made, and agreement reached on the question of state recognition of the Occaneechi Band of the Saponi Nation. 


\section{Notes}

1. I thank Lawrence Dunmore III, Victoria Lindsay Levine, Jason Baird Jackson, Eric Lassiter, Tara Browner, and Valerie Goertzen for commenting on earlier drafts of this essay.

2. North Carolina General statutes $₫ 143 \mathrm{~B}-404$ and $₫ 143 \mathrm{~B}-505$ created the North Carolina Commission of Indian Affairs and set out its duties, which include establishing "appropriate procedures for legal recognition by the State of presently unrecognized groups and tribes." The list of eight criteria for state recognition, written by members of the Commission in 1979, became official in 1980. Sider reprinted the criteria for both state and federal recognition, and explored the simplistic and bizarre character of the latter (1994:19-20). Most North Carolina Tribes with state recognition now seek federal recognition, which does bring with it substantial financial, ideological, and political benefits.

3. The Eastern Band of Cherokee, the only North Carolina tribe to have a reservation or to be federally recognized, chose initially to decline an invitation to join the state Commission. They have participated now and again-responding to the vagaries of their own politics-but are currently (in 1999) not doing so. Their powwows now resemble Southern Plains powwows, e.g. in including gourd dancing, and are so large in terms of both participation and audience, including massive infusions of out-of-state tourists (see Gattuso 1990:309-11), that the Cherokee can ignore the Piedmont/Coastal powwow system that is the focus of this essay. The Indians of Person County, awarded state recognition in 1913, allowed membership on the Commission to lapse, then recently successfully requested reinstatement. They are the only substantial Indian community in the state not to host a powwow, but hope to do so eventually.

4. A small but rising number of North Carolina Indian high school graduates attend college, mostly Lumbee (Oxendine 1995:14). Except at the University of Carolina at Pembroke and several junior colleges, they are very much in the minority, and may do poorly even when well-qualified on paper: their values hamper their prospects (Oxendine 1995:47). Indian clubs which put on powwows foster a sense of community, which in turn makes success in school far more likely.

5. Vargas-Cetina finds a traditional basis for contest powwows: "Just as warriors aimed at 'striking' and 'counting coup,' powwow dancers compete today with other dancers for prizes and recognition. The commercialization of the powwow is, in this sense, an accommodation of previous customs and practices which in this way are kept alive in a modified form" (1988:136). This may be true in plains Indian communities, but the coup-counting conventions of war cannot offer this precedent in Woodlands cultures, where armed conflict between Indian populations is a more distant memory. Toelken notes in his analysis of contest powwows that "while personal competition in and of itself is seen as offensive, competitive demonstration of one's abilities at culturally meaningful expressions, carried out in a culturally determined context, is seen as a positive sign of belonging to, and accepting, ones's own cultural value system" (1991:150). Of course, competition in sports offers a model, both modern generally-popular sports and older specifically Indian ones that at one time were accompanied by music (see Vennum 1994 and Levine 1997).

6 . For other discussions of the values articulated in powwows, see (among many others) Vargas-Cetina 1988:124, Bennett 1991:137-40, and Mattern 1996:199n2.

7. This third powwow is special because "it truly is a homecoming of sorts for many tribal members, who return to the old school of their youth for this event" (Dunmore 1999). A fourth powwow, first held in nearby Mebane Oaks in 1984, now is associated with a small group broken off from the Occaneechi community, and has deteriorated into a hobbyist event. Hobbyists remain important in powwow culture in some parts of the country. Many North Carolina Indians have become wary of them as a category, though a few of these non-Indian enthusiasts who are particularly knowledgeable about and respectful of Indian values and powwow culture-Joe Liles is one-are accepted without reservation.

8. Alcohol seems less of a problem in rural Piedmont and Coastal Indian communities 
than among either reservation Indians (including the Eastern Band of Cherokee) or in urban Indian communities. According to Beltrame and McQueen 1979, Lumbee men at home in Robeson County drink less than do the many Lumbee working in Baltimore, far from family and church. A Cherokee elder made a point of asserting that involvement in powwows "helps boys with family or alcohol problems." None of my Piedmont or Coastal consultants themselves raised these issues, though; when I did so, one told me that a "powwow high" made liquor superfluous.

9. Services at the North Carolina churches that have remained predominantly Indian are overall more explicitly Christian than are powwow blessings, but are beginning to incorporate specifically Indian elements too (Lowry 1999; also see the Lumbee sermons in Snow 1978).

10. Finger describes an experiment one of his Eastern Band of Cherokee consultants made some years ago in connection with "chiefing," i.e., being available by the side of the road for tourist photographs. Henry Lambert "worked one day wearing a warbonnet, the second dressed in modest Cherokee clothing and beadwork, and the third with flashy Plains attire again. The warbonnet and tepee of the Plains tribes brought him $\$ 80$ the first day and $\$ 82$ the third; Cherokee attire on the second netted him only $\$ 3 "$ (1991:161-63). These tourists knew what "real" Indians looked like from their experiences with popular culture. North Carolina powwow emcees may be community leaders, may be members who have gone away, then returned, successful, or may be prestigious Indians from far away, some of whom embody a modern connection with pop culture. Apesanahkwat, the Menominee actor who played Lester Haines on TV's “Northern Exposure," has emceed the Guilford Native powwow (\#25) several times this decade.

11. Jeffries has emceed these powwows, some once, some many times: \#s 1, 2, 3, 4, 6, $8,10,11 \mathrm{~b}, 12 \mathrm{c}, 13,14,15,20,21,23,24,29 \mathrm{~b}, 30 \mathrm{~b}, 31,32,33,34 \mathrm{~b}, 35 \mathrm{a}$, and others not mapped.

12. The "specials" that surprised me most were tightly choreographed display dances by visiting troupes of "Aztec dancers." These small ensembles are extended families from Mexico who make a living at U.S. Latin American festivals and at powwows, sometimes under contract, sometimes as buskers through passing the hat or in a "blanket dance." I have seen "Aztec Dancers" at powwows as small as one at Durham Technical College (\#26a), which may have as few as a dozen North Carolina Indian dancers, and at ones large by local standards such as the Guilford Native powwow (\#25), where "Aztecs" have been featured for over ten years. Their dance outfits, modeled on pictures in centuries-old codices, emphasize bare skin and enormous feathered headdresses. Their purportedly ancient dances resemble ones I've seen at historic pageants put on by students at Mexican universities and by formal folk dance troupes, but don't recall any rural Indian dances of Mexico that I know

"Aztec" can serve as shorthand for "Mexican Indian" in the U.S. When Mexican immigrants-who often are Indians-marry U.S. Indians, the children are described as, e.g., Aztec-Lumbee in Indian circles. However, the spokesman for one "Aztec" troupe told me that the group was from Mexico City, and literally Aztec, though his mother- not part of the show-later, and to her son's marked displeasure, informed me that the family was Tarascan, originally from one of the villages bordering Lake Pátzcuaro. The son had also announced that his group's dances represented unbroken tradition, passed down through the generations in his family, which seemed unlikely to me. On several occasions, I timidly broached the topic of the traditionality of the "Aztec Dancers" in conversation with North Carolina Indians. Each time, I was told that U.S. Indians leave the weighing of authenticity of the "Aztecs" to the "Aztecs," the transparent implication being that I ought to follow suit.

13. North Carolina Indians feel no compelling link with Southern style drumming. Although this style coalesced in Oklahoma, with plenty of input from displaced Southeastern communities, Piedmont and Coastal Plains Indians have no special relationship with, e.g., the descendents of the Cherokee who dodged the Trail of Tears, since many Eastern Cherokee look down on other North Carolina communities ("We fought the white man").

14. The Northern sound has itself been intensified in recent generations. Nettl's older 
Blackfoot consultants remarked that "These young fellows: they sing higher and louder than we used to," and evidence in recordings supported that claim (1989:67).

15. The text very subtly invokes local identity. The vocables that make it up it have a musical function, but also fall into patterns constituting a sort of grammar (see Powers 1987). Few Haliwa-Saponi know Tutelo well enough to hear if the syllables match sound patterns in that language in the way Powers found typical in Lakota song (1992:295), but all can hear that these are not Plains vocables. Cognoscenti can differentiate on the basis of sounds of and patterns of vocables between Haliwa-Saponi songs coming from, e.g., the Seminole and the Chickahominy, not by being linguists, but rather by noticing the recurrence of sets of vocables from song to song.

16. Howard speculated that "participation in Pan-Indian events undoubtably drains performers or potential performers from more distinctly tribal or regional music and dance forms" (1983:81). That makes sense if one believes that there is a predetermined number of Indians who will be involved in expressive culture, and that they choose between involvement in regional music and in powwows. Indeed, the latter idea fits the case of the Ardmore, Oklahoma, Choctaw community that Victoria Levine has studied (1993; pers. com. 1999). However, in North Carolina communities where regional music is now cultivated, this music received less attention before than after the powwow took root. Further, the individuals who devote time to such regional traditions comprise a subset of those who help with powwows, not a different group.

Howard also stated that Pan-Indian powwows often exhibit "a homogeneity . . . approaching that of Howard Johnson restaurants or McDonald hamburger outlets" (1983:74), an opinion I have heard echoed in casual conversation with more than a few scholars: "You know, those cookie-cutter powwows ..." North Carolina Indians savor both the common threads joining and the considerable differences between their various powwows.

\section{References}

Beasley, Cherry. "Health." 1981. Public Policy and Native Americans in North Carolina: Issues for the '80s: Conference Proceedings, edited by Susan M. Presti, 26-44. Raleigh: North Carolina Center for Public Policy Research, Inc.

Beltrame, Thomas, and David V. McQueen. 1979. "Urban and Rural Drinking Patterns: The Special Case of the Lumbee." The International Journal of the Addictions 14(4):53348.

Bennett, Billie Ruth. 1991. "The Role of the Native American Powwow in the Acculturation Process." Ph.D. Dissertation, University of New Mexico.

Brownell, Blaine A. 1971. "The Agrarian and Urban Ideals; Environment Images in Modern America." Journal of Popular Culture 5(3):576-87.

Browner, Tara. 2000. "Making and Singing Pow-Wow Songs: Text, Form, and the Significance of Culture-Based Analysis." Etbnomusicology 44:214-33.

Burton, Bryan. 1993. Moving Within the Circle: Contemporary Native American Music and Dance. Danbury, Connecticut: World Music Press.

Clifford, James. 1988. The Predicament of Culture: Twentieth-Century Lthnography, Literature, and Art. Cambridge: Harvard University Press.

"Editorial: A Tribe is a Tribe." 1997. Raleigh, North Carolina News and Observer, March 10.

Finger, John R. 1991. Cherokee Americans: The Eastern Band of Cherokees in the Twentieth Century. Lincoln: University of Nebraska Press.

Frese, Pamela R., ed. 1993. Celebrations of Identity: Multiple Voices in American Ritual Performance. Westport, Connecticut: Bergin and Garvey.

Gaillard, Frye. 1971. "Cities Contradict Lumbees' Values." Race Relations Reporter 2:6-9.

Gattuso, John, ed. 1990. Insight Guides: Native America. Singapore: Höfer Press.

Gelo, Daniel J. "Powwow Patter: Indian Emcee Discourse on Power and Authority." Journal of American Folklore 112(443):40-57. 
Goertzen, Chris. 1996. "Balancing Local and National Fiddle Styles at American Fiddle Contests." American Music 14(3):352-81.

Guilford Native American Association. 1995. 19th Annual Cultural Festival Powwow. Program.

Haliwa-Saponi Tribe. 1997. Haliwa-Saponi Indian Tribe 32nd Annual Powwow. Program.

Hazel, Forest. 1985. "Black, White \& 'Other': The Struggle for Recognition." In Indians of the South: A Native American Resource Packet, 26-29. Durham, North Carolina: Institute for Southern Studies.

Hirschfelder, Arlene, and Martha Kreipe de Montaño. The Native American Almanac: A Portrait of Native America Today New York: Prentice Hall.

Howard, James H. 1955. "Pan-Indian Culture of Oklahoma." The Scientific Monthly 80:21520.

- 1983. "Pan-Indianism in Native American Music and Dance." Ethnomusicology 27(1):71-82.

Institute for Southern Studies. [1997]. Indians of the South: A Native American Resource Packet Durham, North Carolina: Institute for Southern Studies.

Jabbour, Alan. 1993. "Ethnicity and Identity in America." Folklife Center News 15(2):6-10.

Jeffries, John "Blackfeather." 1997. Interview in his home in Hillsborough, North Carolina.

- 1999. Interview in his home in Hillsborough, North Carolina (by telephone).

Jeffries, Lynette. 1999. Interview in her home in Hillsborough, North Carolina (by telephone). Lawson, John. 1951 [1714]. Lawson's History of North Carolina: Containing the Exact Description and Natural History of that Country, Together with the Present State Thereof and a Journal of a Thousand Miles Traveled Through Several Nations of Indians, Giving a Particular Account of Their Customs, Manners, Etc. Etc. London: Taylor. 1951 Rpt. Richmond: Garrett and Massie.

Lerch, Patricia. 1993. "Powwows, Parades and Social Drama Among the Waccamaw Sioux." In Celebrations of Identity: Multiple Voices in American Ritual Performance, edited by Pamela R. Frese, 75-92. Westport, Connecticut: Bergin and Garvey.

Lerch, Patricia Barker, and Susan Bullers. 1996. "Powwows and Identity Markers: Traditional or Pan-Indian?” Human Organization 55(4):390-95.

Levine, Victoria. 1993. "Musical Revitalization Among the Choctaw." American Music 11(4):391-411.

- 1997. "Music, Myth, and Medicine in the Choctaw Indian Ballgame." In Enchanting Powers: Music in the World's Religions, edited by Lawrence E. Sullivan,190-218. Cambridge: Harvard University Press.

Liles, Joe. 1997. Interview in his home in Durham, North Carolina.

Lowry, Derek. 1999. Interview in his parents' home in Pembroke, North Carolina (by telephone).

Lynch, Dalton. 1997. Interview in his home in Hollister, North Carolina.

Mattern, Mark. 1996. "The Powwow as a Public Arena for Negotiating Unity and Diversity in American Indian Life." American Indian Culture and Research Journal 20(4):183-201.

Merriam, Alan P. 1967. Ethnomusicology of the Flathead Indians. Chicago: Aldine Press.

Nagel, Joane. 1996. American Indian Ethnic Renewal: Red Power and the Resurgence of Identity and Culture. New York: Oxford University Press.

"Native Americans: A Southern Survey." [1997]. In Indians of the South: A Native American Resource Packet, 30-44. Durham, North Carolina: Institute for Southern Studies.

Nettl, Bruno, 1965. "The Songs of Ishi." Musical Quarterly 51(3):460-77.

- 1989. Blackfoot Musical Thought: Comparative Perspectives Kent, Ohio: Kent University Press.

North Carolina Commission of Indian Affairs. 1997. "North Carolina Indians." Broadside.

Noyes, Dorothy. 1995. "Group." In Common Ground: Keywords for the Study of Expressive Culture, a special issue of Journal of American Folklore 108(430):49-478.

Occaneechi-Sapomi. Newsletter published by the Occaneechi-Saponi people beginning in 1995 .

Oxendine, David. 1995. "Racial Identity Development Among Lumbee American Indian Col- 
lege Students on a Predominantly White Campus." M.S. thesis, North Carolina State University.

Perdue, Theda. 1985. Native Carolinians: The Indians of North Carolina. Raleigh: Division of Archives and History, North Carolina Department of Cultural Resources.

Powers, William K. 1987. "The Vocable: An Evolutionary Perspective." In Beyond the Vision: Essays on American Indian Culture, 7-36. Norman: University of Oklahoma Press.

- 1990. War Dance: Plains Indian Musical Performance. Tucson: University of Arizona Press.

- 1992. "Translating the Untranslatable; The Place of the Vocable in Lakota Song." In On the Translation of Native American Literatures, ed. Brian Swann, 293-310. Washington: Smithsonian Institution Press.

Presti, Susan M., ed. 1981. Public Policy and Native Americans in North Carolina: Issues for the '80s: Conference Proceedings. Raleigh: North Carolina Center for Public Policy Research, Inc.

Rochman, Bonnie. "Indian Agency Vetoes Occaneechi Bid for Tribal Status: Lack of Documentation a Barrier to Recognition." Raleigh, North Carolina News and Observer, June 12, 1999.

Ross, Thomas E. 1993. One Land, Three Peoples: A Geography of Robeson County, North Carolina. Southern Pines, North Carolina: Karo Hollow Press.

- 1999. American Indians in North Carolina: Geographic Interpretations. Southern Pines, North Carolina: Karo Hollow Press.

Sider, Gerald M. 1993. Lumbee Indian Histories: Race, Ethnicity and Indian Identity in the Southern United States. Cambridge, England: Cambridge University Press.

Smith, Delores O. [Administrative Law Judge]. 1998. "Recommended Decision, Occaneechi Band of the Saponi Nation, Petitioner, vs. North Carolina Commission of Indian Affairs, Respondent." 96 DOA 0006, Dec. 7.

Smith, Joseph Michael. 1990. The Lumbee Metbodists: Getting to Know Them: A Folk History. Raleigh: Commission of Archives and History, North Carolina Methodist Conference.

Snow, Claude H., Jr. 1977. "An Annotated Transcription of Eight Lumbee Indian Sermons in Upper Robeson County, North Carolina." Ph.D. dissertation, University of North Carolina.

Swimmer, Eddie. 1997. Interview in the tribal offices of the Eastern Band of Cherokee in Cherokee, North Carolina.

Toelken, Barre. 1991. "Ethnic Selection and Intensification in the Native American Powwow." In Creative Ethnicity, edited by Stephen Stern and John Allan Cicala, 137-56. Logan, Utah: Utah State University Press.

Turner, Victor. 1990. "Are There Universals of Performance?" In By Means of Performance: Intercultural Studies of Theatre and Ritual, edited by Richard Schechner and Willa Appel, 8-18. New York: Cambridge University Press.

Ulali. n.d. "Mahk Jchi." On Mabk Jchi, track 6. Compact disc, Original Vision Records.

Vargas-Cetina, Rosa Gabriela. 1988. "The Powwow in Alberta: Hegemony and Tradition Creation." Ph.D. dissertation, University of Calgary.

Velliquette, Beth. 1998. "Occaneechi 1 Step Closer to Recognition." Chapel Hill Herald, Dec. 9.

Vennum, Thomas, Jr. 1994. American Indian Lacrosse: Little Brother of War. Washington, D.C.: Smithsonian Institution Press.

Watson, Linwood. 1997. Interview in his home in Kenly, North Carolina.

Young, Gloria Alese. 1981. "Powwow Power: Perspectives on Historic and Contemporary Intertribalism." Ph.D. dissertation, Indiana University. 